\title{
Effect of rehydration with whey and inoculation with Lactobacillus plantarum and Propionibacterium acidipropionici on the chemical composition, microbiological dynamics, and fermentative losses of corn grain silage
}

\author{
Efeito da reidratação com soro de leite e inoculação com \\ Lactobacillus plantarum e Propionibacterium acidipropionici \\ sobre a composição química, dinâmica microbiológica e perdas \\ fermentativas da silagem de grão de milho
}

\author{
William Luiz de Souza ${ }^{1 *}$; Iorrano Andrade Cidrini²; Arnaldo Prata Neiva Júnior ${ }^{3}$; \\ Mateus Diniz Silva ${ }^{4}$; Jéssica Rocha Sousa Gervásio ${ }^{2}$; Mateus José Inácio de \\ Abreu $^{5}$; Davison Costa Nascimento ${ }^{6}$
}

\section{Highlights:}

Whey has the potential to be used in the rehydration of silage of grain corn.

Rehydration with whey and inoculation improves microbiological dynamics.

Corn grain silages rehydrated with whey and inoculant show less fermentative losses.

Rehydration with whey is a strategy that avoids its disposal in the environment.

\begin{abstract}
The objective of this study was to compare rehydrated corn grain silages using water or whey and inoculated (Lactobacillus plantarum and Propionibacterium acidipropionici) or not. We also verified whether rehydration with whey associated with the bacterial inoculant improves material conservation. The treatments were as follows: silages rehydrated with water without inoculant (SWa); silages rehydrated with water and inoculated (SWaI); silages rehydrated with whey without inoculant (SWe); silages rehydrated with whey and inoculated (SWeI). A completely randomized design was used, with three replications, treatments in a $2 \times 2$ factorial scheme (RE: rehydration with water or whey, and IN: inoculation or addition of water without chlorine), during the following storage periods (T): $0,4,8,16$, 32 , and 64 days. There was an RE $x \mathrm{IN} \times \mathrm{T}$ interaction $(\mathrm{P}<0.001)$ for dry matter $(\mathrm{DM})$, with lower values over time for SWe and higher values in SWeI. An interaction between RE x IN $(\mathrm{P}<0.001)$ and IN $\mathrm{x} \mathrm{T}(\mathrm{P}<0.001)$ was observed for $\mathrm{pH}$, with higher values for $\mathrm{SWe}$ at 64 days of storage and a reduction
\end{abstract}

\footnotetext{
${ }^{1}$ Discente do Curso de Mestrado do Programa de Pós-Graduação em Zootecnia, Universidade Estadual Paulista, UNESP, Jaboticabal, SP, Brasil. E-mail: williamluizdesouzaa@gmail.com

2 Discentes do Curso de Doutorado do Programa de Pós-Graduação em Zootecnia, UNESP, Jaboticabal, SP, Brasil. E-mail: iorranoandrade@gmail.com; jessicagervasio@hotmail.com

3 Prof., Departamento de Zootecnia, Instituto Federal de Educação, Ciência e Tecnologia do Sudeste de Minas Gerais, IF Sudeste MG, Rio Pomba, MG, Brasil. E-mail: arnaldo.junior@ifsudestemg.edu.br

4 Discente do Curso de Mestrado do Programa de Pós-Graduação em Zootecnia, Universidade Federal de Viçosa, UFV, Viçosa, MG, Brasil. E-mail: mateusdinizsilva@hotmail.com

5 Discente do Curso de Graduação em Zootecnia, IF Sudeste MG, Rio Pomba, MG, Brasil. E-mail: abreu.mateusji@gmail.com

6 Discente do Curso de Mestrado do Programa de Pós-Graduação em Zootecnia, Universidade Federal de Lavras, UFLA, Lavras, MG, Brasil. E-mail: davison.costa@hotmail.com

Author for correspondence
} 
from the first days of ensiling for SWaI and SWeI. The microbiological variables showed an RE $\mathrm{x}$ IN $\mathrm{x} T$ interaction $(\mathrm{P}<0.001)$, with the highest counts of lactic acid bacteria for SWaI and SWeI up to 8 days of storage and subsequent higher counts in SWa and SWe. Higher counts were obtained in SWe. For the variables of fermentative losses, there was an RE $x$ IN x T interaction $(\mathrm{P}<0.001)$, with SWeI showing lower losses. The inoculation associated with whey for rehydration of corn grain improved the fermentation profile of the silage, with lower $\mathrm{pH}$ values and reduced losses.

Key words: Lactic acid bacteria. Propionic acid bacteria. Fermentative profile. Grain silage.

\section{Resumo}

O objetivo desse estudo foi comparar as silagens de grão de milho reidratado utilizando água ou soro de leite e inoculados (Lactobacillus plantarum e Propionibacterium acidipropionici) ou não, e verificar se a reidratação com soro associada ao inoculante bacteriano melhora a conservação do material. Os tratamentos foram: silagens reidratadas com água sem inoculante (SA); silagens reidratadas com água com inoculante (SAI); silagens reidratadas com soro de leite inoculante (SS); silagens reidratadas com soro de leite com inoculante (SSI). Foi utilizado um delineamento inteiramente casualizado, com três repetições, tratamentos em esquema fatorial $2 \times 2$ (RE: reidratação com água ou soro de leite, e IN: inoculação ou adição de água sem cloro), durante os períodos de estocagem (T): 0, 4, 8, 16, 32 e 64 dias. Houve interação RE x IN x T $(P<0,001)$ para variável matéria seca (MS) com menores valores ao longo do tempo para SS e valores mais elevados em SSI. Foi observada interação RE x IN $(P<0,001)$ e IN x T $(P<0,001)$ para pH, com maiores valores para SS aos 64 dias de estocagem e redução desde os primeiros dias de ensilagem para SAI e SSI. As variáveis microbiológicas apresentaram interação RE x IN x T $(P<0,001)$, sendo a maior contagem de bactérias ácido láticas para SAI e SSI até os 8 dias de estocagem e após com maiores contagens em SA e SS; maiores contagens foram obtidas em SS. Para as variáveis de perdas fermentativas houve interação RE x IN x T $(P<0,001)$, em geral, com SSI apresentando menores perdas. A inoculação associada ao uso de soro para reidratação de grão de milho melhorou o perfil fermentativo da silagem, com menores valores de $\mathrm{pH}$ e redução das perdas.

Palavras-chave: Bactérias ácido láticas. Bactérias ácido propiônicas, Perfil fermentativo. Silagem de grão.

\section{Introduction}

Corn grain is one of the main ingredients used in diets for confined cattle (Oliveira \& Millen, 2014), accounting for a considerable fraction of the food cost. Processing techniques to improve the efficiency in the use of the starch contained in the corn grain can decrease the production costs. This especially the case for hard corn, which is most commonly used in tropical regions, because of the greater vitreousness of the starch granule (Carareto et al., 2011; Arcari, Martins, Tomazi, \& Santos, 2016). Ensilaging of the corn grain harvested at physiological maturity increases the breakdown of proteins (prolamines) that surround the starch granules, making them more accessible for fermentation by rumen bacteria (Carvalho et al., 2017; Silva et al., 2018). However, in certain circumstances, there may be a delay in harvest, affecting the quality of the silage. Low moisture concentrations restrict fermentation, causing the deterioration of the ensiled material (Windle, Walker, Kung, 2014).

Correcting the humidity of the harvested and ground material to values close to $35 \%$ through the inclusion of water can improve fermentation (Rezende et al., 2014). To achieve this, whey can be used as it is rich in soluble proteins, lactose, minerals, and vitamins, contributing to the fermentation phase and improving the nutritional value of silage (Rezende et al., 2014; El-Shewy, 2016). In addition, serum could also be used for this purpose, as it is a potential cause of environmental damage and cannot be disposed of directly in ponds and rivers. 
The use of inoculants with optional heterofermentative bacteria such as Lactobacillus plantarum, which are efficient in the formation of lactic acid and which produce acetic acid under specific conditions, can help reduce the loss of dry matter during ensiling by providing a rapid lowering of the $\mathrm{pH}$ (Amaral et al., 2020). Propionibacterium acidipropionici bacteria can convert lactic acid to acetic and propionic acid, both effective in controlling fungi and yeasts in ensiled material (Cardoso, Ribeiro, Marcondes, Pereira, \& Wei $\boldsymbol{\beta}, 2019)$. Thus, the association of Lactobacillus plantarum and Propionibacterium acidipropionici can improve the fermentation profile and produce high-quality silage. However, there are few studies combining the use of microbial additives in ground grain silages with rehydration with whey, making further investigations necessary.

We hypothesized that silages rehydrated with whey and inoculated with Lactobacillus plantarum and Propionibacterium acidipropionici will show a rapid decline in the $\mathrm{pH}$ of the medium due to the greater availability of substrates and the greater production of acids associated with the inoculated bacteria, resulting in less proliferation of undesirable microorganisms and, consequently, in lower fermentative losses. The aim of this study was to compare corn silages rehydrated with water or whey, inoculated or not with Lactobacillus plantarum and Propionibacterium acidipropionici, and to verify whether rehydration with serum associated with the bacterial inoculant improves the conservation of ensiled material.

\section{Material and Methods}

Silage process

The experiment was conducted at the Federal Institute of Education, Science and Technology of the Southeast of Minas Gerais, Campus Rio Pomba, and the analyses were performed at the Animal Nutrition Laboratory of the Zootechnics Department. Commercial corn DKB 390 Pro 2, Dekalb, Uberlândia, Brazil (Flint texture), was used, with a moisture content of $13 \%$ (considered dry), and subjected to an electric hammer disintegrator (MFW ${ }^{\circledR}$, model T0 2) with a $4 \mathrm{~mm}$ sieve.

The silages were prepared manually in PVC silos with a diameter of $0.1 \mathrm{~m}$, a height of $0.4 \mathrm{~m}$, and a volume of $3.14 \times 10^{-3} \mathrm{~m}^{3}$, equipped with "Bunsen" valves to allow the free escape of fermentation gases; compaction was carried out with a wooden stick and reached an average density of 1,003 \pm $23 \mathrm{~kg} \mathrm{~m}^{3}$ of natural matter. At the bottom of each silo, $800 \mathrm{~g}$ of dry sand were placed in bags made of non-woven fabric (TNT) to capture the effluent generated during the process; a nylon screen was used to separate the ensiled material from the effluent collection area.

The amount of water or whey necessary to achieve 35\% moisture reconstitution was calculated according to Ferreira (1983). The whey used in the experiment is the result of enzymatic coagulation of milk (cheese making), obtained from the Department of Food Science and Technology of the Federal Institute of Education, Science and Technology of the Southeast of Minas Gerais, Campus Rio Pomba. The serum was homogenized and analyzed in the department's Physical-Chemical Analysis Laboratory (Table 1). 
Table 1

Characteristics of whey (natural matter)

\begin{tabular}{lc}
\hline Item & Whole whey \\
\hline Density, g/L at $15^{\circ} \mathrm{C}$ & 1028.23 \\
$\mathrm{pH}$ & 5.37 \\
Dry matter, \% & 8.89 \\
Crude protein, \% & 0.94 \\
Ether extract, \% & 0.21 \\
Mineral matter, \% & 1.03 \\
\hline
\end{tabular}

The ground corn was mixed manually and received water from an artesian well or whey at room temperature, reaching a moisture content of $35 \%$; some samples received inoculant and were constantly mixed to ensure uniformity of the material. We investigated four different treatments: silages rehydrated with water without inoculant (SWa); silages rehydrated with water using inoculant (SWaI); silages rehydrated with whey without inoculant (SWe); silages rehydrated with whey using an inoculant (SWeI). A completely randomized design was used with three replications and four treatments in a $2 \times 2$ factorial scheme, using the following factors: RE: rehydration with water or whey (correcting for $350 \mathrm{~g} \mathrm{~kg}^{-1}$ of moisture) and IN: inoculation with Lactobacillus plantarum (3.0 x $10^{10} \mathrm{CFU} \mathrm{g}^{-1}$ ) together with Propionibacterium acidipropionici $\left(3.0 \times 10^{10} \mathrm{CFU} \mathrm{g}^{-1}\right)$ or only adding chlorine-free water during the following storage periods (T): $0,4,8,16,32$, and 64 days. The inoculant (LALSIL ${ }^{\circledR}$ Milho) was homogeneously solubilized in water without chlorine at the time of mixing, using the dosage recommended by the manufacturer for silage of rehydrated grains of $5 \mathrm{~g} \mathrm{ton}^{-1}$, with the following composition: Lactobacillus plantarum MA 18/5U $\left(3.0 \times 10^{10} \mathrm{CFU} \mathrm{g}^{-1}\right)$, Propionibacterium acidipropionici MA 26/4U $\left(3.0 \times 10^{10} \mathrm{UFC} \mathrm{g}^{-1}\right)$, and sucrose. The silos were kept in a covered area at room temperature.

\section{Microbiological dynamics}

To a sample of $25 \mathrm{~g}$ of silage, $225 \mathrm{~mL}$ of Ringer's solution were added, and the mixture was homogenized in an industrial blender for 1 minute, obtaining a $10^{-1}$ dilution. Subsequently, successive dilutions were performed to obtain dilutions ranging from $10^{-1}$ to $10^{-7}$ for the cultivation in sterile Petri dishes. We used the pour-plating technique; plates with values between 30 and 300 colony-forming units (UFC) were considered countable. For the counting of lactic acid bacteria (BAL), plating was performed on MRS Agar (Fluka Anylitcal), and the plates were incubated at $35^{\circ} \mathrm{C}$ for 72 hours. The number of enterobacteria (ENT) was determined by plating on Violet Red Bile Glucose Agar (Fluka Analytical), incubated at $35^{\circ} \mathrm{C}$ for 48 hours. Fungi and yeasts were determined by plating on Potato Dextrose Agar (Acumedia), acidified with 10\% (w / v) tartaric acid, after autoclaving and incubated at $25^{\circ} \mathrm{C}$ for a period of 5 days (Cherney \& Cherney, 2003).

\section{Chemical composition and fermentative losses}

The pre-ensiled material and the silages (both in triplicate) were taken to a forced ventilation oven at $55^{\circ} \mathrm{C}$ for 72 hours, using $800 \mathrm{~g}$ per sample, to determine dry matter (DM). Subsequently, the samples were ground in a Willey mill with a 1-mm sieve for the determination of crude protein (CP), 
ether extract (EE), and mineral matter (MM); the $\mathrm{pH}$ was analyzed using fresh samples without grinding, according to the Association of Official Analytical Chemists [AOAC] (1995). Neutral detergent fiber (NDF) and acid detergent fiber (ADF) were determined according to Van Soest, Robertson, \& Lewis (1991), and hemicellulose (HEM) was calculated as the difference between NDF and ADF. Dry matter losses (DML), gaseous losses (GL), and effluent losses (EL), as well as dry matter recovery (DMR), were estimated according to the methodology described by Jobim, Nussio, Reis and Schmidt (2007).

\section{Statistical analysis}

Data were analyzed as repeated measures over time, using PROC MIXED in SAS according to the following model:

$$
\begin{aligned}
Y i j k & =\boldsymbol{\mu}+R E i+I N j+R E \times I N i j+T k+A j: i+ \\
R E \times T i k & +I N \times T j k+R E \times I N \times T i j k+\text { eijk, }
\end{aligned}
$$

in which fixed effects are $\boldsymbol{\mu}=$ general average; $\mathrm{RE}=$ type of rehydration (water; whey); $\mathrm{INj}=$ inoculant (without; with L. plantarum $\left(3.0 \times 10^{10}\right.$ $\left.\mathrm{CFU} \mathrm{\textrm {g } ^ { - 1 }}\right)$, and $P$. acidipropionici $\left(3.0 \times 10^{10} \mathrm{CFU}\right.$ $\left.\mathrm{g}^{-1}\right) ; \mathrm{RE} \times \mathrm{INij}^{=}$interaction between type of rehydration and inoculants; $\mathrm{Tk}=$ storage times for silos (4, 8, 16, 32 and 64 days), time "0" was included in certain variables; $\mathrm{RE} \times \mathrm{Tik}=$ interaction between type of rehydration and storage times; IN $\times \mathrm{Tjk}=$ interaction between inoculants and storage time; RE $\times \mathrm{IN} \times$ Tijk $=$ interaction between type of rehydration, inoculants and storage time; and random effects of $\mathrm{Aj}$ : $\mathrm{i}$ (nested silos in treatment); and $\mathbf{e i j} \mathbf{k}=$ experimental error.

Storage time was included as the option of SAS REPEATED, with the silo was included as subject. Several covariance-to-error structures were investigated, and the structure that best fitted the data according to the lowest value of the Bayesian information criterion (BIC) was selected. The following covariance structures were tested for all variables: UN, UN (1), CS, CSH, TOEP, AR, VC, TOEP (2), ARH (1), ARMA, FA (1), HF, ANTE (1), TOEPH and UNRA covariance structure VC was selected for $\mathrm{pH}$, fungi and yeasts, EL, DM, CP, MM, NDF, and ADF. The HF was selected for LAB, enterobacteria, DML, GL, DMR, and EE. For hemicellulose, ARH (1) was selected. The results were considered significant at the level of $\mathrm{P}<0.05$. The data were analyzed in PROC MIXED of the SAS program (SAS Inst. Inc., Cary, NC), with previous proof of normal distribution (Shapiro-Wilk test) and homoscedasticity of variances (Bartlett test) with a significance level of $\mathrm{P}<0.05$.

\section{Results}

The results obtained for chemical composition, microbiological dynamics, and fermentative losses are shown in Table 2. An interaction was observed between the studied factors $(\mathrm{RE} \times \mathrm{IN} ; \mathrm{P}<0.001)$ for the $\mathrm{pH}$ of the silage, with higher values observed in silages rehydrated with milk without the use of inoculant (5.08) and lower values in silages rehydrated with water without inoculant (4.94), silages rehydrated with water using inoculant (4.84), and silages rehydrated with whey using inoculant (4.78). There also was an interaction between the inoculant (IN) and time (T) factors for the $\mathrm{pH}$ values $(\mathrm{P}<0.001)$, where inoculation promoted a more pronounced drop at the beginning and maintenance of the lowest values throughout the conservation, reaching values of 4.34 and 4.01 for treatments without and with Lactobacillus plantarum and Propionibacterium acidipropionici, respectively, at 64 days of storage (Figure 1).

The DM concentration of the silage showed interaction between the factors evaluated $(\mathrm{RE} \times$ $\mathrm{IN} \times \mathrm{T})(\mathrm{P}<0.001)$, in which silages rehydrated with whey without inoculant showing the lowest values over time (Figure 2, A). Less pronounced reductions were observed in silages rehydrated with whey using an inoculant. 
There were no interactions between the factors $(\mathrm{RE} \times \mathrm{IN})$ and time for the concentrations of crude protein $(\mathrm{CP})$, ether extract $(\mathrm{EE})$, mineral matter (MM), neutral detergent fiber (NDF), acid detergent fiber (ADF), and hemicellulose (HEM) ( $\mathrm{P} \geq 0.054)$. However, $\mathrm{CP}$ increased $(\mathrm{P}<0.01)$ due to rehydration with serum from 86.81 to $88.04 \mathrm{~g} \mathrm{~kg}^{-1}$. There was also a time effect on the concentrations of $\mathrm{CP}$
(Figure 2, B), NDF (Figure 2, C), and HEM (Figure 2 , D) $(\mathrm{P} \leq 0.001)$, where $\mathrm{CP}$ decreased over time from 90,28 to $86.58 \mathrm{~g} \mathrm{~kg}^{-1}$ in the storage periods from 0 to 64 days, respectively, while NDF and HEM had a pronounced reduction until day 4 from 136.15 to $133.05 \mathrm{~g} \mathrm{~kg}^{-1}$ of the NDF and 100.39 to $97.20 \mathrm{~g} \mathrm{~kg}^{-1}$ of HEM, with subsequent concentration stabilization.

Table 2

Chemical composition, microbiological dynamics and fermentative losses of corn grain silages rehydrated with water or whey, using or not inoculating with Lactobacillus plantarum and Propionibacterium acidipropionici and stored for $0,4,8,16,32$, and 64 days

\begin{tabular}{|c|c|c|c|c|c|c|c|c|c|c|c|c|}
\hline \multirow{2}{*}{$\frac{\mathrm{RE}}{\mathrm{IN}}$} & \multicolumn{2}{|c|}{ Water } & \multicolumn{2}{|c|}{ Whey } & \multirow[b]{2}{*}{ SEM } & \multicolumn{7}{|c|}{$P$-value } \\
\hline & $\begin{array}{l}\text { Wi- } \\
\text { thout }\end{array}$ & With & $\begin{array}{l}\text { Wi- } \\
\text { thout }\end{array}$ & With & & RE & IN & $\mathrm{T}$ & $\begin{array}{c}\mathrm{RE} \\
\mathrm{x} \text { IN }\end{array}$ & NL & $\begin{array}{l}\text { IN } \\
\mathrm{x} \mathrm{T} \\
\end{array}$ & $\begin{array}{c}\text { RE x } \\
\text { IN x T }\end{array}$ \\
\hline $\mathrm{pH}$ & 4.94 & & 5.08 & & 0.015 & 0.000 & & & $<0.001$ & 0.309 & $<0.001$ & 0.115 \\
\hline \multicolumn{13}{|c|}{ Chemical composition, $\mathrm{g} \mathrm{kg}^{-1}$ of $\mathrm{DM}$} \\
\hline $\mathrm{DM}^{1}$ & 64.46 & 64.68 & 64.13 & 64.81 & 0.227 & $<0.001$ & $<0.001$ & $<0.001$ & $<0.001$ & 0.006 & $<0.001$ & $<0.001$ \\
\hline $\mathrm{CP}$ & 87.10 & 86.61 & 87.90 & 88.09 & 0.013 & $<0.001$ & 0.106 & $<0.001$ & 0.064 & 0.992 & 0.630 & 0.990 \\
\hline $\mathrm{EE}$ & 35.11 & 35.62 & 35.46 & 35.24 & 0.028 & 0.65 & 0.523 & 0.622 & 0.150 & 0.770 & 0.688 & 0.560 \\
\hline MM & 14.97 & 14.9 & 15.10 & 15. & 0.013 & 0.4 & 0. & & 0.919 & 0.532 & 0.106 & 0.105 \\
\hline NDF & 134.11 & 134.48 & 134.66 & 133 & 0.038 & 0 . & 0.2 & $<0.001$ & 0.054 & 0.284 & 0.707 & 0.311 \\
\hline $\mathrm{ADF}$ & 35.81 & & 35.90 & & 0 . & & & & 0.843 & 994 & 0.977 & 0.988 \\
\hline HEM & 98.30 & 98 & 98.76 & 97.58 & 0.039 & 0.400 & 0.385 & $<0.001$ & 0.070 & 0.275 & 0.789 & 0.291 \\
\hline \multicolumn{13}{|c|}{ Microbiological dynamics, log CFU g ${ }^{-1}$} \\
\hline LAB & 6.10 & 6.02 & 6.28 & 5.97 & 0.020 & 0.002 & $<0.001$ & $<0.001$ & $<0.001$ & 0.011 & $<0.001$ & $<0.001$ \\
\hline ENT & 2.68 & & 2.96 & 2 & 0.019 & $<0.001$ & $<0.001$ & $<0.001$ & $<0.001$ & $<0.001$ & $<0.001$ & $<0.001$ \\
\hline 政 & 4.51 & 4.10 & 4.85 & 4.07 & 0.015 & $<0.001$ & $<0.001$ & $<0.001$ & $<0.001$ & $<0.001$ & $<0.001$ & $<0.001$ \\
\hline \multicolumn{13}{|c|}{ Fermentative losses, $\mathrm{g} \mathrm{kg}^{-1}$ of DM } \\
\hline DML & 14.48 & 11.11 & 24.15 & 9.93 & 0.284 & $<0.001$ & $<0.001$ & $<0.001$ & $<0.001$ & 0.005 & $<0.001$ & $<0.001$ \\
\hline GL & 12.32 & 9.62 & 21.23 & 8.71 & 0.235 & $<0.001$ & $<0.001$ & $<0.001$ & $<0.001$ & 0.036 & $<0.001$ & $<0.001$ \\
\hline $\mathrm{EL}^{2}$ & 2.12 & 1.50 & 2.98 & 1.23 & 0.058 & $<0.001$ & $<0.001$ & $<0.001$ & $<0.001$ & 0.286 & $<0.001$ & 0.098 \\
\hline DMR & 985.52 & 988.89 & 975.85 & 90.07 & 0.284 & $<0.001$ & $<0.001$ & $<0.001$ & $<0.001$ & 0.004 & $<0.001$ & $<0.001$ \\
\hline
\end{tabular}

${ }^{1}$ Units in $\mathrm{g} / \mathrm{kg}$ of natural material. ${ }^{2}$ Units in $\mathrm{kg} / \mathrm{ton}$. of natural matter. RE: Rehydration; IN: Inoculant; DM: Dry matter; CP: Crude protein; EE: Ethereal extract; MM: mineral matter; NDF: neutral detergent fiber; FDA: Fiber in acid detergent; HEM: Hemicellulose; BAL: Lactic acid bacteria; ENT: Enterobacteria; MOFO: Fungi and yeasts; PMS: Loss of dry matter; GL: Gas loss; EL: Effluent loss; DMR: Dry matter recovery; SEM: Standard error of the mean. RE: effect of the rehydration source; $\mathrm{IN}$ : inoculant effect; $\mathrm{T}$ : effect of the storage period; $\mathrm{RE} \times \mathrm{IN}$ : interaction between source of rehydration and inoculant; RE $\times \mathrm{T}$ : interaction between source of rehydration and storage period; $\mathrm{IN} \times \mathrm{T}$ : interaction between inoculant and storage period; $\mathrm{RE} \times \mathrm{IN} \times$ $\mathrm{T}$ : interaction between rehydration source, inoculant and storage period. 
without inoculant - - - with inoculant

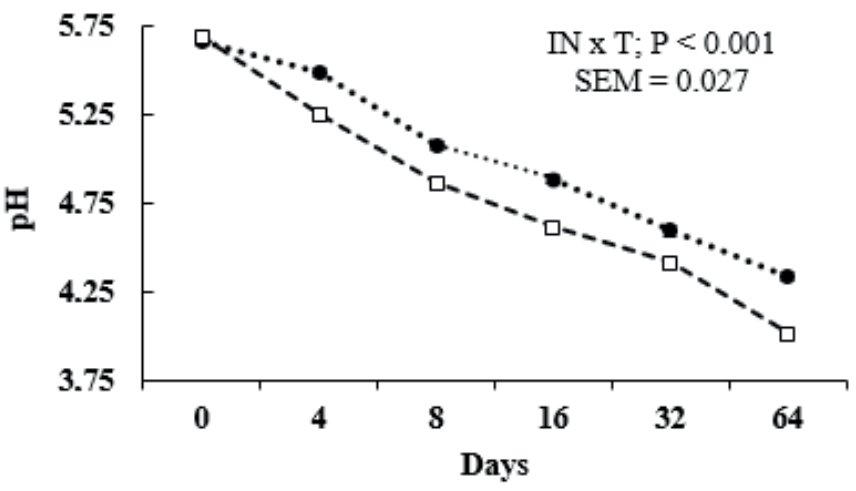

Figure 1. $\mathrm{pH}$ values of corn grain silages rehydrated with water or whey, with or without Lactobacillus plantarum and Propionibacterium acidipropionici and stored for $0,4,8,16,32$, and 64 days.
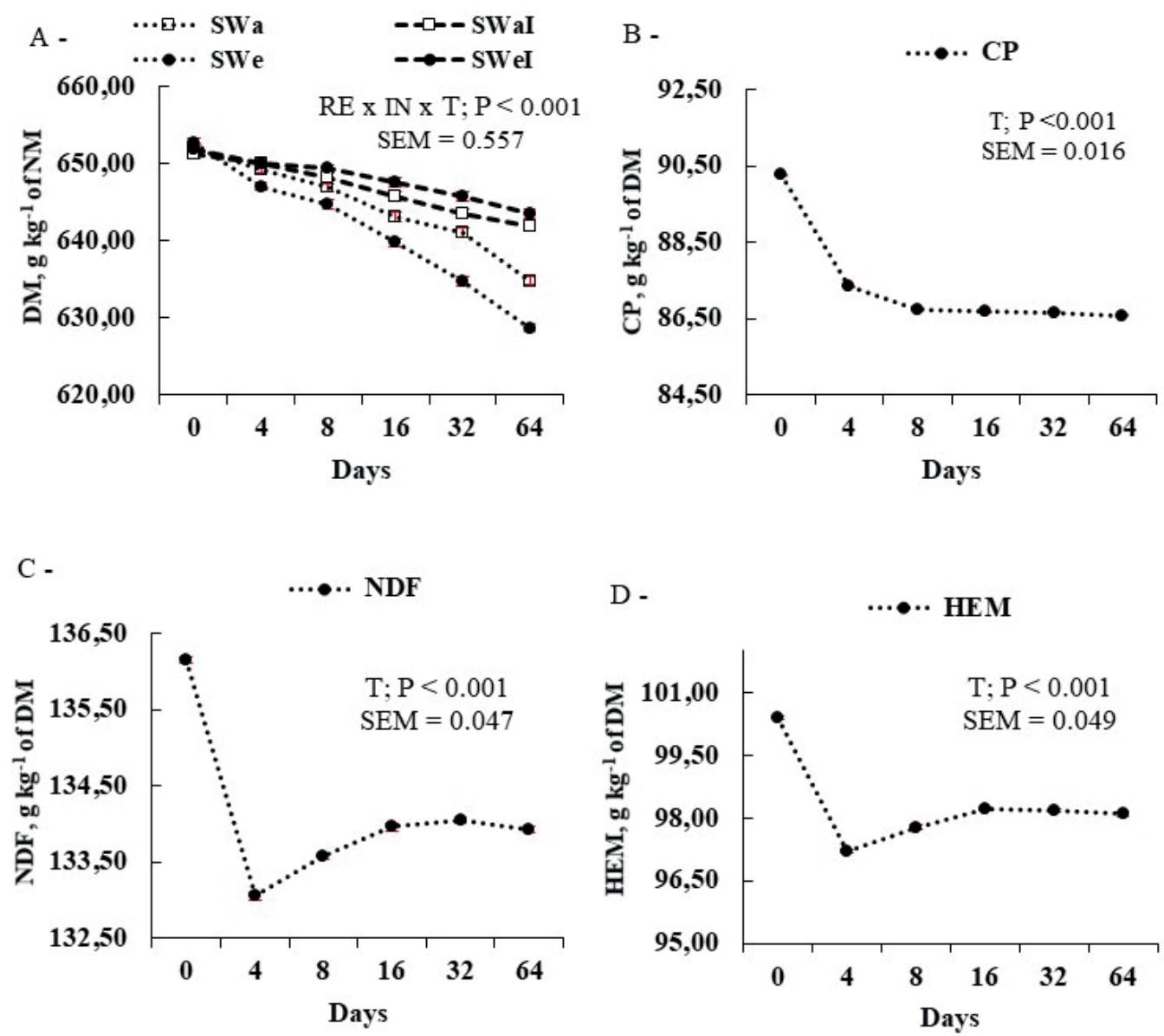

Figure 2. Dry matter content (A), crude protein (B), NDF level (C), and hemicellulose content (D) of corn grain silages rehydrated with water or whey, with or without Lactobacillus plantarum and Propionibacterium acidipropionici and stored for 0, 4, 8, 16, 32, and 64 days. Silages rehydrated with water without inoculant (SWa), silages rehydrated with water with inoculant (SWaI), silages rehydrated with whey without inoculant $(\mathrm{Sw})$, silages rehydrated with whey with inoculant (SWeI). 
In relation to microbiological dynamics, an interaction was observed between the factors studied $(\mathrm{RE} \times \mathrm{IN} \times \mathrm{T})$ for lactic acid bacteria (LAB), enterobacteria (ENT), and fungi and yeasts (MOFO) $(\mathrm{P} \leq 0.001)$. The LAB values were higher up to 8 days of storage in silages rehydrated with water using inoculants and in silages rehydrated with whey using inoculants. Subsequently, there was an inversion, with the highest LAB values for silages rehydrated with water without inoculants and silages rehydrated with whey without inoculants due to the decline in LAB (Figure 3, A). After the peak, with the use of the inoculant, the values of ENT (Figure 3, B) and MOFO (Figure 3, C) were lower over the storage time for silages rehydrated with water using inoculants and silages rehydrated with whey using inoculants; the highest ENT and MOFO counts were observed in silages rehydrated with whey without inoculant, followed by silages rehydrated with water without inoculant.
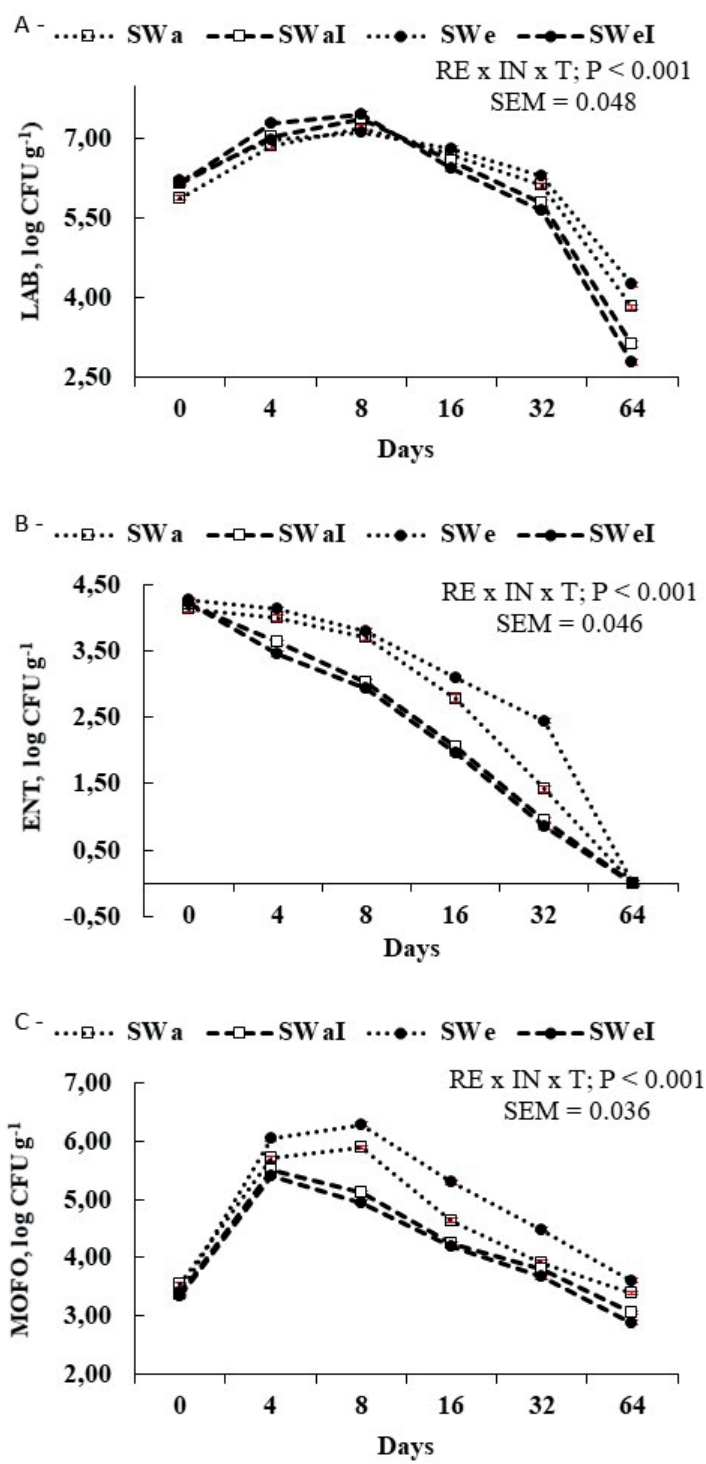

Figure 3. Counts of lactic acid bacteria (A), enterobacteria (B), and fungi and yeasts (C) of corn grain silages rehydrated with water or whey, with or without Lactobacillus plantarum and Propionibacterium acidipropionici and stored for 0, 4, 8, 16, 32, and 64 days. Silages rehydrated with water without inoculant (SWa), silages rehydrated with water with inoculant (SWaI), silages rehydrated with whey without inoculant $(\mathrm{Sw})$, silages rehydrated with whey with inoculant (SWeI). 
For fermentative losses, interactions were verified between the factors $(\mathrm{RE} \times \mathrm{IN} \times \mathrm{T})(\mathrm{P} \leq 0.001)$ for the variables dry matter losses (DML), gas losses (GL), and dry matter recovery (DMR). Throughout the experimental period, DML (Figure 4, A) and GL (Figure 4, B) were higher for silages rehydrated with whey without inoculants, with lower RMS values. In contrast, silages rehydrated with whey and inoculants showed lower DML and GL values, with higher DMR values (Figure 4, D). There was an interaction between the factors $(\mathrm{RE}$ and $\mathrm{IN} ; \mathrm{P} \leq$
0.001) for effluent losses (EL) (Figure 4, C), and the lowest losses were verified in inoculated silages, with a lower value for silages rehydrated with whey and inoculant. The highest EL values were obtained in silages rehydrated with whey without inoculant. There was also an interaction between the IN factor and $\mathrm{T}$ for $\mathrm{EL}(\mathrm{P} \leq 0.001)$, where the inoculated treatments had a lower PE until 8 days of storage; subsequently, the value remained below those of the other treatments until the end of the experiment.
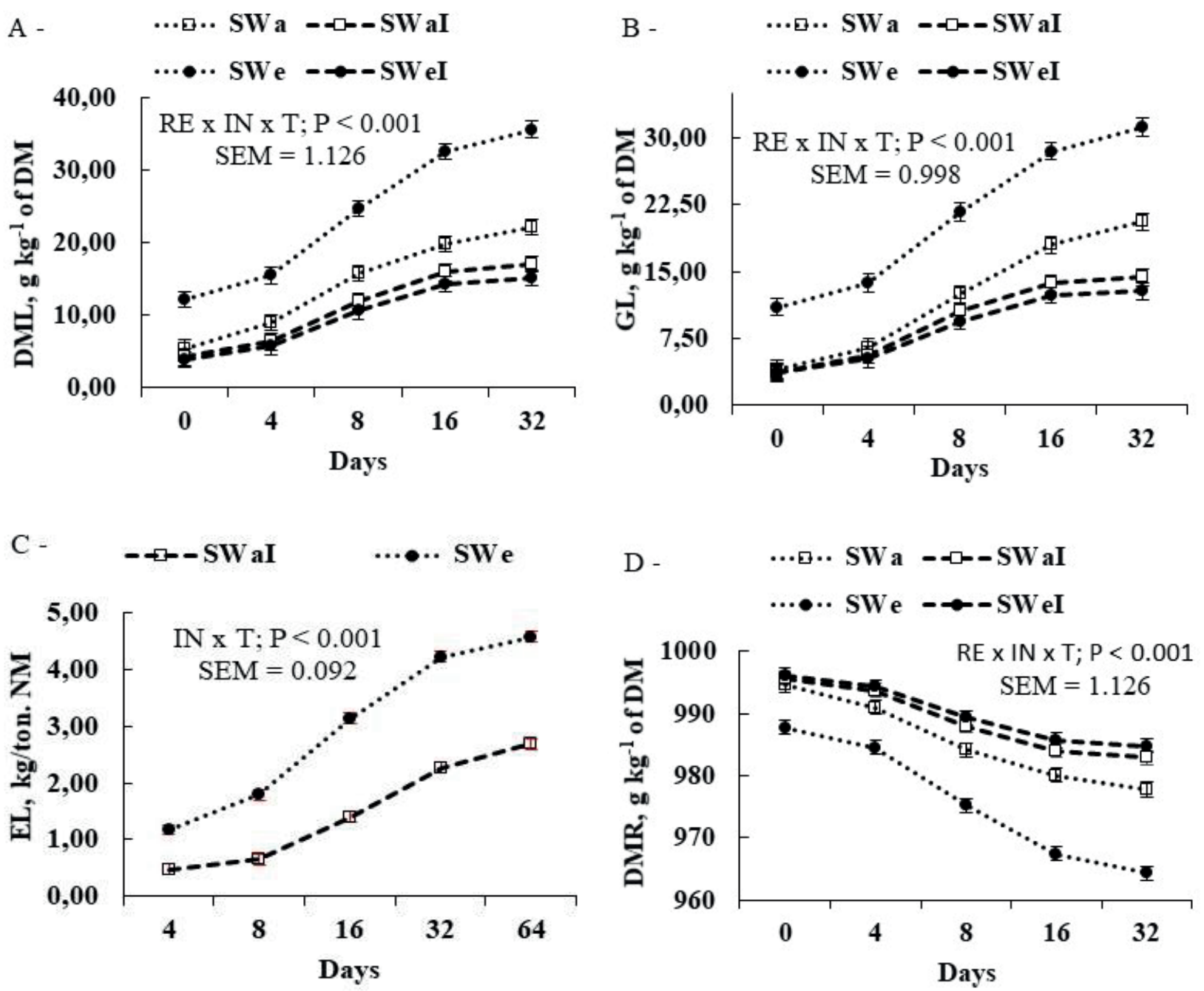

Figure 4. Dry matter losses (A), gas losses (B), effluent losses (C), dry matter recovery (D) of corn grain silages rehydrated with water or whey, with or without Lactobacillus plantarum and Propionibacterium acidipropionici and stored for 0, 4, 8, 16, 32, and 64 days. Silages rehydrated with water without inoculant (SWa), silages rehydrated with water with inoculant (SWaI), silages rehydrated with whey without inoculant (Sw), silages rehydrated with whey with inoculant (SWeI). 


\section{Discussion}

The increase in the concentration of acids, mainly acetic and propionic acids, favors the beginning of the $\mathrm{pH}$ reduction inside the silo and directly influences the population dynamics of bacteria. Given this, homofermentative bacteria can emerge, which are more efficient in the production of lactic acid, promoting a faster drop in $\mathrm{pH}$ and ensuring favorable conditions for the conservation of the ensiled mass (Mombach, Pereira, Santos Pina, Pereira, \& Bolson, 2018). In this way, Lactobacillus plantarum is characterized as an optional heterofermentative bacterial species with efficient lactic acid production, providing a reduction in $\mathrm{pH}$. Propionibacterium acidipropionici is a heterofermentative bacterium that efficiently produces propionic acid, acting in the control of fungi and yeasts and maintaining low $\mathrm{pH}$ values (Yitbarek \& Tamir, 2014; Michel et al., 2017). For better nutrient conservation, the $\mathrm{pH}$ should reach values between 3.8 and 4.2 (McDonald, 1981). In the present study, at 64 days of storage, only the silage rehydrated with whey without inoculant did not present values within this ideal range, indicating a higher number of undesirable microorganisms in storage, consequently, greater losses.

Whey contains high levels of soluble carbohydrates (lactose) (Nishanthi, Vasiljevic, \& Chandrapala, 2017). It is possible to consider that lactic acid bacteria use the soluble carbohydrates of whey for their growth, resulting in a greater production of lactic acid and in a lower $\mathrm{pH}$ value.

Lactic acid bacteria are classified into three groups: homofermentative, mandatory heterofermentative, and facultative heterofermentative. Homofermentative bacteria use the Embden-Meyerhof-Parnas pathway, with the final fermentation product being only lactic acid and metabolizing hexoses. Mandatory heterofermentatives use the 6-phosphogluconate/ phosphoquetolase pathway, resulting in $1 \mathrm{~mol}$ of lactic acid, $1 \mathrm{~mol}$ of $\mathrm{CO}_{2}$, and 1 methanol or acetic acid. Furthermore, pentoses can only be metabolized by heterofermentative pathways, while optional heterofermentatives can use homofermentative and heterofermentative pathways, use hexoses and, under specific conditions, can ferment pentoses (Vinderola, Ouwehand, Salminen, \& Von Wright, 2019).

The change in the profile of lactic acid bacteria in which the mandatory heterofermentatives start fermentation is the replacement by homofermentatives(Vinderola etal.,2019). In the first 60 days after ensiling, homofermentatives dominate; afterwards, facultative heterofermentatives start to gain importance due to the greater resistance to low $\mathrm{pH}$ levels and the reduction of the substrate for homofermentatives (Zhou, Drouin, \& Lafrenière, 2016).

The ideal $\mathrm{pH}$ for the growth of enterobacteria is between 6.0 and 7.0; they do not develop at $\mathrm{pH}$ levels below 5.0 (Muck, 2010; Gharechahi et al., 2017) and are inhibited by stable temperatures and low humidity (Yitbarek \& Tamir, 2014). Still, lactic acid bacteria compete for substrate with undesirable microorganisms such as fungi, bacteria of the genus Clostridium, and enterobacteria at the beginning of the fermentation process (Yitbarek \& Tamir, 2014).

The stable phase of the silage occurs at the moment when the ensiled mass reaches the $\mathrm{pH}$ necessary to reduce and control microbial activities (Anjos et al., 2018); otherwise, there will be a possibility of breaking stability (Pires et al., 2013). There is evidence of changes in the nutritional quality of the ensiled material during the conservation period due to the presence of microorganisms resistant to low pH values, such as yeasts (Leão et al., 2017). The bacterium Propionibacterium acidipropionici can ferment sugars and lactate to acetate and propionate; these short-chain aliphatic acids inhibit yeast growth (Cardoso et al., 2019).

Working with wet corn gluten bran, França et al. (2015) observed that a longer ensiling period reduced the yeast and fungus counts, decreasing 
linearly from 7.2 to $5.5 \log \mathrm{UFC} \mathrm{g}^{-1}$ of silage between 1 and 42 days of ensiling, due to the reduction of the concentration of oxygen in the silo. This is because the counts of fungi and yeasts during the first 8 days of silage are related to the epiphytic population in the material to be ensiled (Ávila, Bravo Martins, \& Schwan, 2010). Borreani and Tabacco (2010) observed higher counts of fungi and yeasts in the peripheral regions of silos, areas with higher concentrations of oxygen.

One of the reasons for greater dry matter losses is the loss of gas and effluent, resulting in nutrient losses (Ferraretto, Crump, \& Shaver, 2013). The lower the dry matter losses, the greater the dry matter recovery of the ensiled material. When comparing the values of gas losses, Rabelo et al. (2012), working with corn silage at different stages of maturity, observed a small variation in losses by effluents (12.2 to $13.5 \mathrm{~kg} \mathrm{t}^{-1}$ of natural matter) due to bacterial inoculation; effluent losses were influenced by the humidity of the ensiled material. Therefore, in our study, the recommended humidity was $35 \%$, preventing high effluent losses.

The formation of gas in the silage is the result of secondary fermentation promoted by enterobacteria, Clostridium species, and aerobic microorganisms, which normally grow in environments with a higher pH (Muck, 2010). The reduction of gas losses is probably due to the reduction of the action of these gas-producing microorganisms that develop in the silage under unfavorable conditions, gases from the conversion of proteins and carbohydrates by microorganisms that produce several components from them, such as organic acids, ethanol, water, ATP, and $\mathrm{CO}_{2}$ (Edvan et al., 2013; Rigueira, Pereira, Ribeiro, Mantovani, \& Agarussi, 2013). According to Muck (2010), several species of enterobacteria use nitrate as an electron acceptor instead of oxygen, reducing nitrate to nitrite or even nitrogen oxide, which has a low volatilization point, increasing gas losses during the fermentation process.

Bacterialinoculantscontaininghomofermentative bacteria increase the recovery of dry matter during fermentation due to the use of more efficient metabolic pathways in the production of lactic acid, rapidly reducing silage $\mathrm{pH}$ (Muck, 2010). The dry matter contents were higher for silages rehydrated with whey with the use of inoculants due to lower dry matter losses, the greater supply of solid compounds contained in whey in relation to rehydration with water, and mainly because of the improvement with the use of inoculants. The reduction in crude protein can be explained by the increased loss of dry matter through icroorganisms, causing the dilution of the protein in dry matter (Campos, Lana, Galvão, Souza, \& Tavares, 2017). The contents of NDF and hemicellulose decreased over time, which may be related to the solubilization of the cellulose and hemicellulose fractions. Rezende et al. (2014) observed that the NDF contents were reduced during the fermentation process due to the reduction of hemicellulose, which was consumed during fermentation. Therefore, these differences can be attributed to the biochemical variations that occur during the ensiling process. The reduction in the hemicellulose content can be associated with its acid hydrolysis, which results from the activity of the enzyme hemicellulase, produced by bacteria present in the ensiled material; hydrolysis occurs through the presence of acids produced during fermentation (Araújo et al., 2020).

\section{Conclusion}

The rehydration of corn grains with whey, associated with the use of inoculant (Lactobacillus plantarum and Propionibacterium acidipropionici), improves the fermentation profile of the silage, with lower $\mathrm{pH}$ values and fermentation losses.

\section{Acknowledgments}

We thank Federal Institute of Education, Science and Technology of the Southeast of Minas Gerais and the Zootechnics Department of the Campus Rio Pomba for supporting this work. 


\section{References}

Amaral, R. C., Carvalho, B. F., Costa, D. M., Morenz, M. J. F., Schwan, R. F., \& Silva Ávila, C. L. da. (2020). Novel lactic acid bacteria strains enhance the conservation of elephant grass silage cv. BRS Capiaçu. Animal Feed Science and Technology, 264(1), 114472. doi: 10.1016/j.anifeedsci.2020.114472

Anjos, G. V. S. dos, Gonçalves, L. C., Rodrigues, J. A. S., Keller, K. M., Coelho, M. M., Michel, P. H. F.,... Jayme, D. G. (2018). Effect of re-ensiling on the quality of sorghum silage. Journal of Dairy Science, 101(7), 6047-6054. doi: 10.3168/jds.2017-13687

Araújo, C. A., Santos, A. P. M., Figueiredo Monteiro, C. C., Lima, D. O., Torres, A. M., Santos, C. V. S.,... Silva, J. J. (2020). Efeito do tempo de ensilagem sobre a composição química, perfil fermentativo e estabilidade aeróbia de silagens de milho (Zea mays). Diversitas Journal, 5(1), 547-561. doi: 10. 17648/diversitas-journal-v5i1-1035

Arcari, M. A., Martins, C. M. D. M. R., Tomazi, T., \& Santos, M. V. dos. (2016). Effect of the ensiling time of hydrated ground corn on silage composition and in situ starch degradability. Brazilian Journal of Veterinary Research and Animal Science, 53(1), 6071. doi: 10.11606/issn.1678-4456.v53i1p60-71

Association of Official Analytical Chemists (1995). Official methods of analysis (16nd ed.). Washington, D.C.: AOAC.

Ávila, C. L. S., Bravo Martins, C. E. C., \& Schwan, R. F. (2010). Identification and characterization of yeasts in sugarcane silages. Journal of Applied Microbiology, 109(5), 1677-1686. doi: 10.1111/j.1365-2672.2010.04796.x

Borreani, G., \& Tabacco, E. (2010). The relationship of silage temperature with the microbiological status of the face of corn silage bunkers. Journal of Dairy Science, 93(6), 2620-2629. doi: 10.3168/jds.20092919

Campos, S. A., Lana, R. P., Galvão, J. C. C., Souza, M. N., \& Tavares, V. B. (2017). Efeito do esterco de galinha poedeira na produção de milho e qualidade da silagem. Revista Ceres, 64(3), 274-281. doi: 10. 1590/0034-737x201764030008

Carareto, R., Santos, F. A. P., Mourao, G. B., Pedroso, A. M., Sitta, C., Soares, M. P., \& Soares, M. C. (2011). Corn grain processing methods and forage levels on diets for finishing Nellore bulls. Journal of Animal Science, 89(Suppl. 1), 115 (Abstr.).
Cardoso, L. L., Ribeiro, K. G., Marcondes, M. I., Pereira, O. G., \& Weiß, K. (2019). Chemical composition and production of ethanol and other volatile organic compounds in sugarcane silage treated with chemical and microbial additives. Animal Production Science, 59(4), 721-728. doi: 10.1071/AN1620

Carvalho, B. F., Ávila, C. L. S., Bernardes, T. F., Pereira, M. N., Santos, C., \& Schwan, R. F. (2017). Fermentation profile and identification of lactic acid bacteria and yeasts of rehydrated corn kernel silage. Journal of Applied Microbiology, 122(3), 589-600. doi: 10.1111/jam.13371

Cherney, J. H., \& Cherney, D. J. R. (2003). Assessing silage quality. In D. R. Buxton R. E. Muck, \& J. H Harrison. (Eds.), Silage science and technology (pp.141-198). Madison, Wisconsin: American Society of Agronomy. doi: 10.2134/agronmonogr42. c4

Edvan, R. L., Carneiro, M. S. S., Coutinho, M. J. F., Silva, E. B., Oliveira, G. S., Silva, M. S. M., \& Albuquerque, D. R. (2013). Perdas e composição bromatológica de silagem de gliricídia contendo diferentes níveis de vagem de algaroba. Tecnologia \& Ciência Agropecuária, 7(2), 63-68.

El-Shewy, A. A. (2016). Whey as a feed ingredient for lactating cattle. Science International, 4(3), 80-85. doi: $10.17311 /$ sciintl.2016.80.85

Ferraretto, L. F., Crump, P. M., \& Shaver, R. D. (2013). Effect of cereal grain type and corn grain harvesting and processing methods on intake, digestion, and milk production by dairy cows through a metaanalysis. Journal of Dairy Science, 96(1), 533-550. doi: $10.3168 /$ jds.2012-5932

Ferreira, W. A. (1983). Armazenamento de grãos de cereais. In M. P. Cereda, L. Sanches (Eds.), Manual de armazenamento e embalagem de produtos agropecuários (pp. 96-128). Botucatu: UNESP.

França, A. M. S., Ferreira, I. C., Hermisdorff, Í. D. C., Mendonça, E. P., Fernandes, E. D. A., \& Rossi, D. A. (2015). Dinâmica química, microbiológica e física da silagem de farelo úmido de glúten de milho. Ciência Rural, 45(4), 684-689. doi: 10.1590/0103$8478 \mathrm{cr} 20140716$

Gharechahi, J., Kharazian, Z. A., Sarikhan, S., Jouzani, G. S., Aghdasi, M., \& Hosseini Salekdeh, G. (2017). The dynamics of the bacterial communities developed in maize silage. Microbial Biotechnology, 10(6), 1663-1676. doi: 10.1111/1751-7915.12751

Jobim, C. C., Nussio, L. G., Reis, R. A., \& Schmidt, P. (2007). Avanços metodológicos na avaliação 
da qualidade da forragem conservada. Revista Brasileira de Zootecnia, 36(Supl. Spe.), 101-119. doi: 10. 15 90/S1516-35982007001000013S

Leão, G. F. M., Jobim, C. C., Neumann, M., Horst, E. H., Santos, S. K. D., Venancio, B. J., \& Santos, L. C. (2017). Nutritional composition and aerobic stability of winter cereal silage at different storage times. Acta Scientiarum. Animal Sciences, 39(2), 131-136. doi: 10.4025 /actascianimsci.v39i2.34270

McDonald, P. (1981). The biochemistry of silage. Chichester: John Wiley \& Sons, Ltd.

Michel, P. H. F., Gonçalves, L. C., Rodrigues, J. A. S., Keller, K. M., Raposo, V. S., Lima, E. M. \& Jayme, D. G. (2017). Re-ensiling and inoculant application with Lactobacillus plantarum and Propionibacterium acidipropionici on sorghum silages. Grass and Forage Science, 72(3), 432-440. doi: 10.1111/ gfs. 12253

Mombach, M. A., Pereira, D. H., Santos Pina, D. do, Pereira, O. G., \& Bolson, D. C. (2018). Rehydration of dry corn grain as an alternative for conservation purposes. Australian Journal of Crop Science, 12(9), 1472. doi: 10.21475/ajcs.18.12.09.PNE1155

Muck, R. E. (2010). Silage microbiology and its control through additives. Revista Brasileira de Zootecnia, 39(Supl. Spe.), 183-191. doi: 10.1590/S1516-35982 010001300021

Nishanthi, M., Vasiljevic, T., \& Chandrapala, J. (2017). Properties of whey proteins obtained from different whey streams. International Dairy Journal, 66(1), 76-83. doi: 10.1016/j.idairyj.2016.11.009

Oliveira, C. A., \& Millen, D. D. (2014). Survey of the nutritional recommendations and management practices adopted by feedlot cattle nutritionists in Brazil. Animal Feed Science and Technology, 197(8), 64-75. doi: 10.1016/j.anifeedsci.2014.08.010

Pires, D. A. A., Rocha, V. R. J., Sales, E. C. J., Reis, S. T., Jayme, D. G., Cruz, S. S.,... Esteves, B. L. C. (2013). Características das silagens de cinco genótipos de sorgo cultivados no inverno. Revista Brasileira de Milho e Sorgo, 12(1), 68-77. doi: 10.18512/19806477/rbms.v12n1p68-77

Rabelo, C. H. S., Rezende, A. V., Nogueira, D. A., Rabelo, F. H. S., Senedese, S. S., Vieira, P. F.,... Carvalho, A. (2012). Perdas fermentativas e estabilidade aeróbia de silagens de milho inoculadas com bactérias ácidoláticas em diferentes estádios de maturidade. Revista Brasileira Saúde Produção Animal, 13(3), 656-668. doi: 10.1590/S1519-99402012000300006
Rezende, A. V., Rabelo, C. H., Veiga, R. M., Andrade, L. P., Härter, C. J., Rabelo, F. H.,... \& Reis, R. A. (2014). Rehydration of corn grain with acid whey improves the silage quality. Animal Feed Science and Technology, 197(11), 213-221. doi: 10.1016/j. anifeedsci.2014.07.009

Rigueira, J. P. S., Pereira, O. G., Ribeiro, K. G., Mantovani, H. C., \& Agarussi, M. C. N. (2013). The chemical composition, fermentation profile, and microbial populations in tropical grass silages. Revista Brasileira de Zootecnia, 42(9), 612-621. doi: 10.1590/S1516-35982013000900002

Silva, N. C. da, Nascimento, C. F., Nascimento, F. A., Resende, F. D. de, Daniel, J. L. P., \& Siqueira, G. R. (2018). Fermentation and aerobic stability of rehydrated corn grain silage treated with different doses of Lactobacillus buchneri or a combination of Lactobacillus plantarum and Pediococcus acidilactici. Journal of Dairy Science, 101(5), 41584167. doi: $10.3168 /$ jds.2017-13797

Van Soest, P. V., Robertson, J. B., \& Lewis, B. A. (1991). Methods for dietary fiber, neutral detergent fiber, and nonstarch polysaccharides in relation to animal nutrition. Journal of Dairy Science, 74(10), 35833597. doi: 10.3168/jds.S0022-0302(91)78551-2

Vinderola, G., Ouwehand, A., Salminen, S., \& Von Wright, A. (Eds.). (2019). Lactic acid bacteria: microbiological and functional aspects. Boca Raton, Florida: Crc Press.

Windle, M. C., Walker, N., \& Kung, L., Jr. (2014). Effects of an exogenous protease on the fermentation and nutritive value of corn silage harvested at different dry matter contents and ensiled for various lengths of time. Journal of Dairy Science, 97(5), 3053-3060. doi: $10.3168 /$ jds.2013-7586

Yitbarek, M. B., \& Tamir, B. (2014). Silage additives: review. Open Journal of Applied Sciences, 4(5), 258274. doi: 10.4236/ojapps.2014.45026

Zhou, Y., Drouin, P., \& Lafrenière, C. (2016). Effect of temperature (5-25 C) on epiphytic lactic acid bacteria populations and fermentation of whole plant corn silage. Journal of Applied Microbiology, 121(3), 657-671. doi: 10.1111/jam.13198 
